\title{
INTEGRASI SERVQUAL DAN AHP UNTUK EVALUASI KUALITAS LAYANAN DEKRANASDA
}

\author{
A. Aviv Mahmudi \\ Program Studi Manajemen-S1 STIE YPPI Rembang \\ Jl. Raya Rembang-Pamotan KM. 4 Rembang \\ Email: viva.althaf@gmail.com
}

\begin{tabular}{|c|c|}
\hline rtikel : & ABSTRACT \\
\hline \multirow[t]{2}{*}{$\begin{array}{l}\text { Sejarah Artikel : } \\
\text { Menerima : } \\
\text { 21 Des 2020 } \\
\text { Revisi : } \\
\text { 29 Des 2020 } \\
\text { Diterima : } \\
\text { 13 Jan 2021 } \\
\text { Online : } \\
\text { 15 Jan 2021 } \\
\text { Keyword : AHP, } \\
\text { Dekranasda, } \\
\text { Service Quality, } \\
\text { Customers. }\end{array}$} & $\begin{array}{l}\text { Achieving superior service quality is the main concern of all service providers, } \\
\text { so that service providers are urged to provide high quality customer-oriented } \\
\text { services. The purpose of this study was to analyze the quality of customer } \\
\text { service at Dekranasda Rembang, using the Servqual and Analitycal Hierarchy } \\
\text { Process (AHP) methods. Servqual is used to see customer perceptions and } \\
\text { expectations on the five dimensions of servqual including Physical Evidence } \\
\text { (Tangibles), guarantee (Reliability), Responsiveness (Responsiveness), } \\
\text { Assurance (Assurance) and Empathy (Emphaty). While AHP is used to weight } \\
\text { each dimension and criteria. The results showed that there were } 10 \text { service } \\
\text { criteria that had to be improved immediately by Dekranasda, so as to improve } \\
\text { customer quality. }\end{array}$ \\
\hline & \\
\hline $\begin{array}{l}\text { Kata Kunci: } \\
\text { AHP, } \\
\text { Dekranasda, } \\
\text { Kualitas layanan, } \\
\text { Pelanggan. }\end{array}$ & $\begin{array}{l}\text { Mencapai kualitas layanan yang unggul menjadi perhatian utama bagi semua } \\
\text { penyedia layanan, sehingga penyedia layanan dituntut untuk menyediakan } \\
\text { layanan dengan kualitas tinggi yang berorientasi pada pelanggan. Tujuan } \\
\text { penelitian ini adalah melakukan analisis kualitas layanan pelanggan pada } \\
\text { Dekranasda Kabupaten Rembang, dengan menggunakan metode Servqual dan } \\
\text { analitycal Hierarchy Procces (AHP). Servqual digunakan untuk mengetahui } \\
\text { persepsi dan harapan pelanggan pada kelima dimensi servqual diantaranya } \\
\text { Bukti Fisik (Tangibles), Keandalan (Reliability), Daya Tanggap } \\
\text { (Responsiveness), Jaminan (Assurance) dan Empati (Emphaty). Sedangkan } \\
\text { AHP digunakan untuk pembobotan masing-masing dimenssi dan kriteria. } \\
\text { Hasil penelitian menujukkan ada 10 kriteria layanan yang harus segera } \\
\text { dilakukan perbaikan oleh Dekranasda, sehingga mampu meningkatakan } \\
\text { kualiatas pelanggan. }\end{array}$ \\
\hline
\end{tabular}




\section{PENDAHULUAN}

Pada era teknologi maju yang semakin kompetitif, memberikan pengaruh yang besar terhadap berbagai hal aspek kehidupan manusia, yang mengarah pada peningkatan harapan orang. Pelanggan mencari barang dengan kualitas lebih baik serta layanan yang memuaskan. Oleh karena itu, pasar dunia telah menjadi semakin kompetitif. Faktor terpenting untuk mengatasi persaingan adalah memberikan kualitas yang lebih baik Banyak perusahaan yang berusaha meningkatkan jumlah pelanggannya dengan meningkatkan pelanggan kepuasan dengan layanan dan produk yang lebih baik (Yazdi, 2015). Untuk tujuan ini, perusahaan wajib melakukannya menilai kualitas layanan mereka. Secara umum, kepuasan pelanggan sebanding dengan kualitas layanan yang ditawarkan (Hosseini dan Keshavarz , 2017).

Layanan merupakan suatu aktivitas atau serangkaian aktivitas yang biasanya tidak bersifat intangible, terjadi dalam interaksi antara pelanggan dan karyawan layanan dan/atau sumber daya fisik atau barang dan/atau sistem penyedia layanan (Shirouyehzad et al, 2013). Mengukur kepuasan pelanggan merupakan salah satu tantangan terbesar dalam melakukan layanan yang berkualitas. Kualitas layanan mempengaruhi kepuasan klien, oleh karena itu mengukur kesenjangan antara pelanggan dan persepsi penyedia layanan tentang kualitas layanan akan membantu mengidentifikasi kualitas layanan yang sebenarnya dalam perusahaan (Juanzon, 2019).

Layanan sangat diperlukan bagi perusahaan untuk terus memperkuat posisi pasar dan kaitannya dengan pesaing. Servqual merupakan salah satu metode untuk pengukuran kualitas layanan yang didasarkan pada lima dimensi kualitas layanan yaitu: tangibility, reliability, responsiveness, assurance dan empathy (Singh, 2016). Setiap oraganisasi/perusahaan diharapkan selalu melakukan perbaikan kualitas layanan pada pelanggan dengan tujuan untuk dapat selalu berkembang (Hosseini dan Keshavarz, 2017). Identifikasi dimensi dan indikator terpenting dari setiap permasalahan layanan juga mampu peringkatankan berdasarkan dari skala keterpentingan (Yazdi, 2015).

Ada beberapa metode untuk mengevaluasi kualitas layanan. Servqual (service quality) merupakan suatu pendekatan kualitas layanan yang membandingkan persepsi pelanggan atas layanan nyata yang mereka terima (Perceived Service) dengan layanan yang sesungguhnya yang diharapkan/diinginkan (Expected Service). Jika kenyataan lebih dari yang diharapkan, maka layanan dapat dikatakan bermutu, sedangkan jika kenyataan kurang dari yang diharapkan, maka layanan dikatakan tidak bermutu (Parasuraman, 1985 et al). Pada penelitian ini analisis servqual (service quality) digunakan secara kualitatif untuk mengidentifikasi poin-poin penting layanan pelanggan sehingga membantu UKM Produk Kerajinan dalam melayani dan memenuhi kebutuhan pelanggan. Dimesi Servqual merupakan alat yang dapat digunakan untuk mengukur kinerja layanan

Beberapa penelitian pemanfaatan servqual untuk kualitas layanan diantaranya pendekatan Fuzzy Sevqual digunakan untuk melakukan penilaian kualitas layan rumah sakit, dengan melakukan perhitungan skor persepsi, harapan dan kesenjangan (Behdioglu et al, 2017). Servqual juga digunakan untuk mengukur/mengevaluasi kualitas layanan kesehatan berkelanjutan dan kepuasan pasien pada rumah sakit di Zonguldak/Turki (Pekkaya et al, 2017). Kombinasi QFD (Quality Function Deployment) dan servqual juga dilakukan untuk menganalisis hubungan dengan pelanggan. Kedua kombinasi tersebut mengidentifikasi kebutuhan pelanggan dari perspektif kepuasan pelanggan, sedangkan untuk bobot kebutuhan pelanggan mengggunakan metode (AHP). Efektifitas ketiga metode tersebut menghasilkan keakuratan analisis data sehingga dapat digunakan untuk dasar dalam menetapkan saran dan rekomendasi layanan perbaikan kualitas perbankan (Gao dan Zhou, 2018).

AHP adalah metode pengambilan keputusan multi kriteria (MCDM) yang membantu pengambil keputusan dalam menghadapi masalah kompleks dengan mengguankan beberapa kriteria yang saling bertentangan dan subjektif (Lupo, 2013). AHP terbukti memiliki keakuratan yang baik dalam menentukan kualitas (Darmanto, 2014). Metode AHP juga lebih cepat dalam proses pengambian keputusan dibandingkan perhitungan secara manual sehingga bisa lebih efesien dan memliki tingkat keakuratan data yang baik (Rahman, 2019). 
Penerapan AHP dan servqual juga telah terbukti efektif dalam penilaian kepuasan pelanggan, servqual digunakan untuk mengetahui sejauh mana terjadinya kesenjangan antara persepsi dan harapan pelanggan yang berdampak pada terwujudnya kepuasan pelanggan. Sedangkan metode AHP digunakan untuk memberikan atribut variable dimensi servqual berdasarkan tingkat kepentingan atribut (Suciani, 2016). Penerapan AHP yang dikomparasikan dengan servqual juga telah memberikan indikasi yang jelas bagi perusahan dalam penilaian kualitas layanan sehingga dapat membantu pengambilan keputusan bagi manajerial untuk meningkatkan kualitas layanan di masa depan atau meningkatkan jumlah pusat layanan (Zhu et al, 2011).

Berdasarkan uraian sebelumnya, tujuan dari penelitian ini adalah untuk mengembangkan metodologi berbasis servqual dengan tujuan untuk mengidentifikasi layanan yang berkualitas pada pelanggan, sedangkan metode AHP diadopsi sebagai alat untuk memperkirakan bobot kepentingan dari dimensi dan atribut layanan.

\section{METODE PENELITIAN}

a. Objek penelitian

Objek penelitian ini adalah Dekranasda (Dewan Kerajinan Nasional Daerah) Kabupaten Rembang Jawa Tengah. Dekranasda merupakan showroom untuk memamerkan dan menjual produk UKM di Kabupaten Rembang diantaranya Batik Tulis Lasem dan produk kerajinan tangan lainnya.

b. Metode Pengumpulan Data

Data Primer, diperoleh langsung dari pengelola/manajemen UKM Dekranasda Kabupaten Rembang dari hasil wawancara serta kuesioner dengan pihak manajemen dan juga 29 pemilik UKM dan pelanggan UKM produk Kerajinan. Serta data sekunder, yaitu data yang diperoleh dari sumber tertulis yaitu sumber buku dan artikel ilmiah.

c. Populasi dan Sampel

Populasi yang menjadi objek penelitian ini adalah pelanggan yang telah membeli produk kerajinan pada Dekranasda Kabupaten Rembang. Teknik pengambilan sampel menggunakan purposive sampling. Sedangkan penentuan responden menggunakan accidental sampling, yaitu pengambilan sampel berdasarkan pertemuan antara peneliti saat pelanggan membeli produk kerajinan, sejumlah 100 responden.

d. Metode Analisis data

Pada tahap pengolahan data, semua data yang diperoleh dari responden melalui penyebaran kuesioner akan diolah dengan menggunakan metode yang telah ditentukan.

1) Metode Servqual

Metode servqual adalah metode yang sering digunakan untuk mengukur kualitas layanan. Dalam metode servqual terdapat lima faktor utama atau dimensi servqual yang menentukan kualitas pelayanan. yaitu:

a) Bukti langsung (tangibles); meliputi fasilitas fisik, perlengkapan, pegawai, dan sarana komunikasi

b) Keandalan (reliability); yakni kemampuan memberikan pelayanan yang dijanjikan dengan segera, akurat, dan memuaskan

c) Daya tanggap (responsiveness); yaitu keinginan para staf untuk membantu para pelanggan dan memberikan pelayanan dengan tanggap

d) Jaminan (assurance); mencakup pengetahuan, kemampuan, kesopanan, dan sifat dapat dipercaya yang dimiliki para staf, bebas dari bahaya, risiko, atau keraguraguan

e) Empati (empathy); meliputi kemudahan dalam melakukan hubungan, komunikasi yang baik, perhatian pribadi, dan memahami kebutuhan para pelanggan Untuk kuesioner sebagaiamana Tabel 1, berikut:

Tabel 1. Hasil Tabulasi Kuesioner

\begin{tabular}{|l|l|}
\hline \multicolumn{2}{|l|}{ Bukti Fisik (Tangibles) } \\
\hline 1 & Dekranasda memiliki lokasi yang strategis $(\mathrm{X} 1.1)$ \\
\hline 2 & Dekranasda memiliki ruang kantor yang bersih $(\mathrm{X} 1.2)$ \\
\hline 3 & Kondisi lingkungan gedung yang bersih dan nyaman $(\mathrm{X} 1.3)$ \\
\hline 4 & Ketersediaan ruang tunggu yang nyaman (X1.4) \\
\hline
\end{tabular}




\begin{tabular}{|l|l|}
\hline 5 & Karyawan perusahaan berpenampilan rapi dan professional (X1.5) \\
\hline 6 & Brosur dan fasilitas layanan lain tertata dengan rapi (X1.6) \\
\hline Keandalan (Reliability) \\
\hline 7 & Pelayanan sesuai dengan janji yang diberikan (X2.1) \\
\hline 8 & Karyawan memberikan layanan tepat pada waktunya (X2.2) \\
\hline 9 & Jenis layanan yang diberikan telah sesuai dengan yang ditawarkan (X2.3) \\
\hline 10 & Karyawan menginformasikan kepada pelanggan tentang produk-produknya (X2.4) \\
\hline 11 & Pelayanan pengaduan cepat dan handal (X2.5) \\
\hline 12 & Karyawan dapat diandalkan dalam menangani masalah jasa pelanggan (X2.6) \\
\hline Daya Tanggap (Responsiveness) \\
\hline 13 & Karyawan selalu menunjukkan kesabaran dan perhatian terhadap pelanggan (X3.1) \\
\hline 14 & Karyawan memberikan informasi yang dibutuhkan oleh pelanggan secara tepat (X3.2) \\
\hline 15 & Karyawan selalu merespon keluhan pelanggan dengan cepat (X3.3) \\
\hline 16 & Karyawan siap membantu pelanggan bila mengalami kesulitan (X3.4) \\
\hline 17 & Karyawan merespon permintaan pelanggan dengan cepat, tepat dan efisien (X3.5) \\
\hline 18 & Karyawan selalu dapat menyelesaikan keluhan pelanggan (X3.6) \\
\hline Jaminan (Assurance) \\
\hline 19 & Kemampuan karyawan dapat dipercaya (X4.1) \\
\hline 20 & Karyawan memiliki kompetensi dan profesional dalam melayani pelanggan (X4.2) \\
\hline 21 & Karyawan terampil dalam melayani pelanggan (X4.3) \\
\hline 22 & Karyawan mampu menjawab setiap pertanyaan pelanggan (X4.4) \\
\hline 23 & Karyawan menumbuhkan rasa percaya kepada pelanggan (X4.5) \\
\hline 24 & Pelanggan merasa aman dalam melakukan transaksi (X4.6) \\
\hline Empati (Emphaty) \\
\hline 25 & Karyawan segera meminta maaf saat terjadi kesalahan (X5.1) \\
\hline 26 & Karyawan memberikan perhatian secara individual kepada para pelanggan (X5.2) \\
\hline 27 & Karyawan memahami kebutuhan spesifik pelanggan (X5.3) \\
\hline 28 & Karyawan mengutamakan kepentingan pelanggan (X5.4) \\
\hline 29 & Karyawan mudah dihubungi oleh pelanggan (X5.5) \\
\hline 30 & Pelayanan pada pelanggan tidak membedakan status social (X5.6) \\
\hline
\end{tabular}

\section{2) Metode Analitycal Hierarchy Process (AHP)}

Metode AHP digunakan untuk mengevaluasi kualitas layanan pada pelanggan Dekranasda dengan melakukan pembobotan pada lima dimensi servqual serta pada butir-butir pernyataan. AHP yang diusulkan oleh Thomas L. Saaty pada awal tahun 1970-an, AHP merupakan salah satu metode analisis pengambilan keputusan yang populer. AHP memungkinkan memecahkan permasalahan dan menghasilkan solusi untuk menangani permasalah yang kompleks (Juanzon, 2019). Dalam mengolah data dengan metode AHP dapat dilakukan dengan cara berikut (Awasthi et al, 2018):

a) Penentuan Prioritas

b) Untuk setiap kriteria dan alternatif, perlu dilakukan perbandingan berpasangan (pairwise comparisons). Nilai-nilai perbandingan relatif kemudian diolah untuk menentukan peringkat alternatif dari seluruh alternatif.

c) Perhitungan konsistensi logis, perhitungan konsistensi logis dapat dilakukan dengan mengikuti langkah-langkah sebagai berikut:

(1) Mengalikan matriks dengan prioritas bersesuaian

(2) Menjumlahkan hasil perkalian per baris

(3) Hasil penjumlahan tiap baris dibagi prioritas bersangkutan dan hasilnya dijumlahkan.

(4) Hasil dari Langkah (3) dibagi jumlah elemen, akan didapat $\lambda$ max.

(5) Indeks konsistensi $(\mathrm{CI})=(\lambda \max -\mathrm{n}) /(\mathrm{n}-1)$

(6) Rasio Konsistensi = CI/RI, dimana RI adalah indeks random konsistensi. Jika rasio konsistensi $=0,1$ maka hasil perhitungan dapat dibenarkan.

(7) Nilai RI merupakan nilai random indeks yang dikeluarkan oleh Oarkridge Laboratory yang berupa Tabel 2 berikut: 
Tabel 2. Nilai Random Indeks

\begin{tabular}{|c|c|c|c|c|c|c|c|c|c|}
\hline Ukuran Matriks & 2 & 3 & 4 & 5 & 6 & 7 & 8 & 9 & 10 \\
\hline IR & 0,00 & 0,58 & 0,90 & 1,12 & 1,24 & 1,32 & 1,41 & 1,45 & 1,51 \\
\hline
\end{tabular}

Sumber: Saaty (1994)

\section{HASIL DAN ANALISA}

Survei servqual menyentuh kepuasan pelanggan dengan melihat layanan proses, serta hasil yang diharapkan dalam layanan yang disediakan, terhadap persepsi layanan yang diterima pelanggan yang meliputi: bukti fisik (tangibles), keandalan (reliability), daya tanggap (responsiveness), jaminan (assurance), dan empati (empathy) organisasi layanan. Grading yang paling standar dari servqual survei adalah ukuran gap dimana hasilnya menunjukkan area layanan organisasi harus diperbaiki (Kumar et al, 2008).

Dimensi reliability (keandalan) yang mencerminkan kemampuan untuk melaksanakan jasa yang diharapkan dan akurat. Dimensi responsiveness meliputi kemauan untuk membantu pelanggan dan memberikan layanan yang cepat. Dimensi assurance merupakan indikasi dari pengetahuan dan kesopanan dari pemberi layanan dan kemampuan mereka untuk menginspirasi kepercayaan dan keyakinan. Dimensi empathy meliputi perhatian secara personal kepada pelanggan (Udo, 2011).

Hasil tabulasi kuisioner pendahuluan kemudian dijadikan acuan dalam menyusun berbagai instrumen dalam dimensi kualitas pelayanan. Hasil Tabulasi dapat dilihat pada Tabel 1 dengan kebaikan yakni terdapat keseragaman skor (variability of scorer) sebagai konsekuensi dari penggunaan skala yang berkisar antara 1 sampai 5 .

\section{Uji Instrumen}

Pengambilan data dari 100 sampel penelitian dengan data 50 sampel penelitian yang bisa digunakan untuk uji validas dan uji reliabilitas. Uji instrumen dalam penelitian ini menggunakan 50 responden. Uji instrumen yang digunakan adalah uji validitas dan uji reliabilitas. Hasil dari uji validitas dan uji reliabilitas adalah sebagai berikut:

a. Uji Reliabilitas

Uji Reliabilitas digunakan untuk mengetahui konsistensi alat ukur yang digunakan. Reliabilitas dalam penelitian ini menggunakan nilai Cronbach's Alpha di atas 0,7. Semakin tinggi nilai cronbach's alpha berarti semakin tinggi tingkat reliabilitas alat ukur yang digunakan. Berikut hasil reliabilitas instrumen penelitian:

\section{Tabel 3. Hasil Uji Reliabilitas}

\begin{tabular}{lccc}
\hline \multicolumn{1}{c}{ Variabel } & Cronbach Alpha & Standar & Ket \\
\hline Variabel Bukti Fisik (Tangibles) & 0,714 & 0,70 & Reliabel \\
Variabel Keandalan (Reliability) & 0,852 & 0,70 & Reliabel \\
Daya Tangkap (Responsiveness) & 0,804 & 0,70 & Reliabel \\
Variabel Jaminan (Assurance) & 0,873 & 0,70 & Reliabel \\
Variabel Empati (Emphaty) & 0,701 & 0,70 & Reliabel \\
\hline
\end{tabular}

Berdasarkan hasil uji reliabilitas Tabel 3 di atas, maka dapat diketahui bahwa variabelvariabel dalam penelitian ini dinyatakan reliabel karena nilai Cronbach Alpha lebih besar dari standarisasi reliabel yaitu 0,70 .

b. Uji Validitas

Dalam uji validitas, untuk mengetahui kueisioner yang digunakan valid atau tidak adalah dengan membandingkan nilai $r_{\text {hitung }}$ dengan $r_{\text {tabel. }}$. Jika nilai $r_{\text {hitung }}$ lebih besar dari nilai $r_{\text {tabel }}$ maka 
kuseioner adalah valid (Ghozali, 2011). Adapun besarnya nilai $r_{\text {tabel }}$ diperoleh dari Tabel $r$ dengan terlebih dahulu mencari nilai df. Dalam penelitian ini nilai df adalah sebesar 48 yang diperoleh dengan menggunakan rumus yaitu: $\mathrm{df}=\mathrm{n}-2$, di mana $\mathrm{n}$ adalah jumlah sampel yang digunakan untuk uji instrumen, sehingga $\mathrm{df}=50-2$ adalah 48 .

1) Uji Validitas Variabel Bukti Fisik (Tangibles)

Hasil uji validitas variabel kemasan adalah sebagaimana tersaji pada Tabel 4 berikut:

Tabel 4. Hasil Validitas Variabel Bukti Fisik (Tangibles)

\begin{tabular}{cccc}
\hline Pernyataan & $\mathrm{r}_{\text {hitung }}$ & $\mathrm{r}_{\text {tabel }}$ & Keterangan \\
\hline 1 & 0,622 & 0,2787 & Valid \\
\hline 2 & 0,530 & 0,2787 & Valid \\
\hline 3 & 0,486 & 0,2787 & Valid \\
\hline 4 & 0,794 & 0,2787 & Valid \\
\hline 5 & 0,625 & 0,2787 & Valid \\
\hline 6 & 0,689 & 0,2787 & Valid
\end{tabular}

Berdasarkan Tabel 4, maka dapat diketahui bahwa pernyataan pada variabel Bukti Fisik (tangibles) adalah semua valid karena nilai $r_{\text {hitung }}>$ dari $r_{\text {tabel }}$.

2) Uji Validitas Variabel Keandalan (Reliability)

Hasil uji validitas variabel keandalan adalah sebagaimana tersaji pada Tabel 5

Tabel 5. Hasil Validitas Variabel Keandalan (Reliability)

\begin{tabular}{cccc}
\hline Pernyataan & $\mathrm{r}_{\text {hitung }}$ & $\mathrm{r}_{\text {tabel }}$ & Keterangan \\
\hline 7 & 0,712 & 0,2787 & Valid \\
\hline 8 & 0,831 & 0,2787 & Valid \\
\hline 9 & 0,895 & 0,2787 & Valid \\
\hline 10 & 0,620 & 0,2787 & Valid \\
\hline 11 & 0,612 & 0,2787 & Valid \\
\hline 12 & 0,875 & 0,2787 & Valid
\end{tabular}

Berdasarkan Tabel 5, maka dapat diketahui bahwa pernyataan pada variabel keandalan (reliability) adalah semua valid karena nilai $r_{\text {hitung }}>$ dari $r_{\text {tabel }}$.

3) Uji Validitas Variabel Daya Tangkap (Responsiveness)

Hasil uji validitas variabel daya tangkap adalah sebagaimana tersaji pada Tabel 6 .

Tabel 6. Hasil Validitas Variabel Daya Tangkap (Responsiveness)

\begin{tabular}{cccc}
\hline Pernyataan & $\mathrm{r}_{\text {hitung }}$ & $\mathrm{r}_{\text {tabel }}$ & Keterangan \\
\hline 13 & 0,750 & 0,2787 & Valid \\
\hline 14 & 0,574 & 0,2787 & Valid \\
\hline 15 & 0,852 & 0,2787 & Valid \\
\hline 16 & 0,707 & 0,2787 & Valid \\
\hline 17 & 0,819 & 0,2787 & Valid \\
\hline 18 & 0,551 & 0,2787 & Valid
\end{tabular}

Berdasarkan Tabel 6, maka dapat diketahui bahwa pernyataan pada variabel daya tangkap (responsiveness) adalah semua valid karena nilai $\mathrm{r}_{\text {hitung }}>$ dari $\mathrm{r}_{\text {tabel. }}$.

4) Uji Validitas Variabel Jaminan (Assurance)

Hasil uji validitas variabel Jaminan adalah sebagaimana tersaji pada Tabel 7

Tabel 7. Hasil Validitas Variabel Jaminan (Assurance)

\begin{tabular}{cccc}
\hline Pernyataan & $\mathbf{r}_{\text {hitung }}$ & $\mathbf{r}_{\text {tabel }}$ & Keterangan \\
\hline 19 & 0,664 & 0,2787 & Valid \\
\hline 20 & 0,646 & 0,2787 & Valid \\
\hline 21 & 0,569 & 0,2787 & Valid \\
\hline 22 & 0,720 & 0,2787 & Valid \\
\hline 23 & 0,658 & 0,2787 & Valid \\
\hline 24 & 0,666 & 0,2787 & Valid \\
\hline
\end{tabular}


Berdasarkan Tabel 7, maka dapat diketahui bahwa pernyataan pada variabel jaminan (assurance) adalah semua valid karena nilai $\mathrm{r}_{\text {hitung }}>$ dari $\mathrm{r}_{\text {tabel }}$.

5) Uji Validitas Variabel Empati (Emphaty)

Hasil uji validitas variabel empati adalah sebagaimana tersaji pada Tabel 8

\begin{tabular}{cccc}
\multicolumn{3}{c}{ Tabel 8. Hasil Validitas } & \multicolumn{3}{c}{ Variabel Empati (Emphaty) } \\
\hline Pernyataan & $\mathbf{r}_{\text {hitung }}$ & $\mathbf{r}_{\text {tabel }}$ & Keterangan \\
\hline 25 & 0,581 & 0,2787 & Valid \\
\hline 26 & 0,786 & 0,2787 & Valid \\
\hline 27 & 0,516 & 0,2787 & Valid \\
\hline 28 & 0,560 & 0,2787 & Valid \\
\hline 29 & 0,683 & 0,2787 & Valid \\
\hline 30 & 0,564 & 0,2787 & Valid \\
\hline
\end{tabular}

Berdasarkan Tabel 8, maka dapat diketahui bahwa pernyataan pada Variabel empati (emphaty) adalah semua valid karena nilai $r_{\text {hitung }}>$ dari $r_{\text {tabel }}$.

\section{Perhitungan Nilai Gap Kualitas Pelayanan UKM Dekranasda}

Nilai gap dari perhitungan kualitas pelayanan di UKM Dekranasda dihitung berdasarkan nilai rata-rata dari skor persepsi dan skor harapan nasabah. Hasil perhitungan gap dapat dilihat pada Tabel 8. Berdasarkan nilai keseluruhan negatif kecuali daya tangkap (responsiveness). Nilai negatif tersebut menunjukkan kurang berkualitas dan kurang memuaskan. Nilai positif menunjukkan perhitungannya untuk kualitas pelayanan berkulitas dan memuaskan.

Tabel 9. Rekapitulasi Perhitungan Gap Kualitas Pelayanan

\begin{tabular}{|c|c|c|c|c|c|}
\hline \multirow[b]{2}{*}{ No } & \multirow[b]{2}{*}{ Dimensi } & \multicolumn{2}{|c|}{ Nilai Rata-Rata } & \multirow[b]{2}{*}{ Gap } & \multirow[b]{2}{*}{ Keterangan } \\
\hline & & $\begin{array}{l}\text { Persepsi } \\
\text { (X) }\end{array}$ & $\begin{array}{l}\text { Harapan } \\
\text { (Y) }\end{array}$ & & \\
\hline 1 & $\begin{array}{l}\text { Bukti Fisik } \\
\text { (Tangibles) }\end{array}$ & 4,013 & 4,273 & $-0,259$ & $\begin{array}{l}\text { Kurang berkualitas dan kurang } \\
\text { memuaskan }\end{array}$ \\
\hline 2 & $\begin{array}{l}\text { Keandalan } \\
\text { (Reliability) }\end{array}$ & 4,153 & 4,364 & $-0,210$ & $\begin{array}{l}\text { Kurang berkualitas dan kurang } \\
\text { memuaskan }\end{array}$ \\
\hline 3 & $\begin{array}{l}\text { Daya Tangkap } \\
\text { (Responsiveness) }\end{array}$ & 4,227 & 4,121 & 0,105 & Berkualitas dan memuaskan \\
\hline 4 & Jaminan (Assurance) & 4,253 & 4,364 & $-0,110$ & $\begin{array}{l}\text { Kurang berkualitas dan kurang } \\
\text { memuaskan }\end{array}$ \\
\hline 5 & Empati (Emphaty) & 4,190 & 4,242 & $-0,052$ & $\begin{array}{l}\text { Kurang berkualitas dan kurang } \\
\text { memuaskan }\end{array}$ \\
\hline
\end{tabular}

\section{Pembobotan AHP}

Metode pembobotan AHP dilakukan untuk menilai tingkat kepentingan dari variabel kualitas pelayanan yang diberikan oleh Dekranasda Kabupaten Rembang terhadap pelanggan. Pembobotan dilakukan oleh 4 (empat) unsur yang memahami tentang Dekranasda, diantaranya Dinindagkop Kabupaten Rembang, Forum Komunikasi UMKM Rembang, FEDEP Rembang, Ketua Klaster Batik Tulis Lasem Rembang. Berdasarkan metode AHP, tahapan pertama yang dilakukan adalah menentukan bobot masing-masing dimensi servqual. Pemberian bobot dilakukan dengan sistem matriks perbandingan berpasangan. setiap kriteria memiliki tingkat kepentingan yang berbeda, sehingga bobot yang diberikan juga tentu berbeda. Pembobotan ini dilakukan dengan melakukan perbandingan berpasangan pada 5 (lima) dimensi servqual yaitu Bukti fisik (Tangibles), Keandalan (Reliability), Daya Tangkap (Responsiveness), Jaminan (Assurance), Empati (Emphaty). Matriks perbandingan berpasangan sebagaimana Gambar 1.

\begin{tabular}{|c|c|c|c|c|c|}
\hline Kriteria & $\begin{array}{l}\text { Bukti Fisik } \\
\text { (Tangibles) }\end{array}$ & $\begin{array}{l}\text { Keandalan } \\
\text { (Reliability) }\end{array}$ & $\begin{array}{l}\text { Daya Tangkap } \\
\text { (Responsiveness) }\end{array}$ & $\begin{array}{c}\text { Jaminan } \\
\text { (Assurance) }\end{array}$ & $\begin{array}{c}\text { Empati } \\
\text { (Emphaty) }\end{array}$ \\
\hline Bukti Fisik (Tangibles) & 1 & $1 / 3$ & $1 / 5$ & 2 & 3 \\
\hline Keandalan (Reliability) & 3 & 1 & 2 & 5 & 7 \\
\hline $\begin{array}{l}\text { Daya Tangkap } \\
\text { (Responsiveness) }\end{array}$ & 5 & $1 / 2$ & 1 & 3 & 7 \\
\hline Jaminan (Assurance) & $1 / 2$ & $1 / 5$ & $1 / 3$ & 1 & 3 \\
\hline Empati (Emphaty) & $1 / 3$ & $1 / 7$ & $1 / 7$ & $1 / 3$ & 1 \\
\hline
\end{tabular}


Selanjutnya dilakukan penjumlahan matriks banding berpasangan selanjutnya untuk normalisasi matriks dilakukan dengan cara membagi masing-masing angka di setiap kolom dengan jumlah kolom masing-masing dan dilanjutkan dengan menghitung nilai rata-rata di masing-masing baris. Rata-rata baris ini memberikan tingkat preferensi dari kelima dimensi. Priority Vector (kolom paling kanan) menunjukan bobot dari masing-masing kriteria.
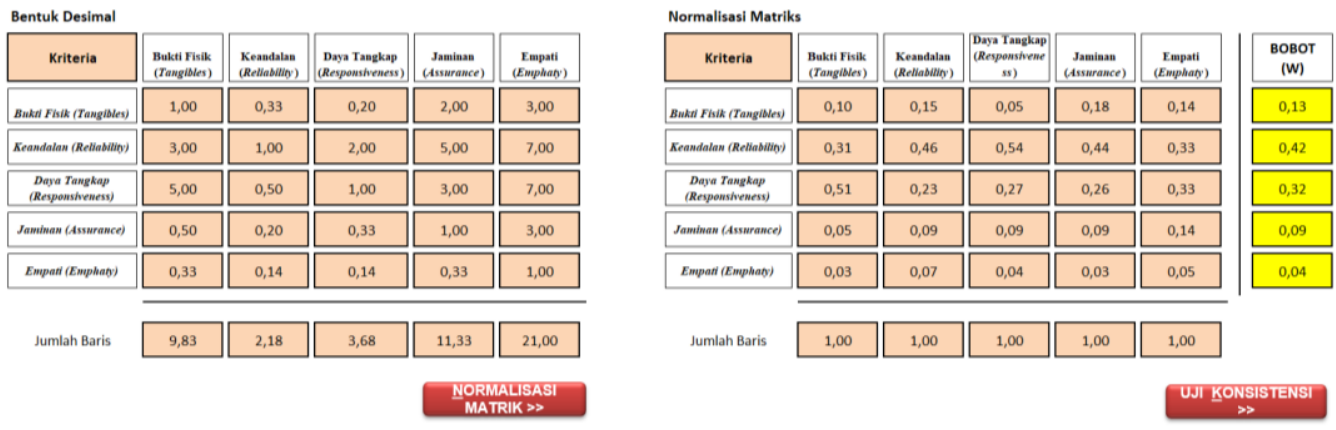

Gambar 2. Normalisasi Matriks

Membuat peringkat alternatif dari matriks pairwise masing-masing dimensi dengan menentukan eigenvector setiap dimensi. Cara yang digunakan sama ketika membuat peringkat prioritas di atas. Langkahnya dengan menentukan matriks pairwise comparisons masing-masing alternatif, menentukan nilai eigenvector masing-masing alternatif, menentukan peringkat alternatif, peringkat alternatif dapat ditentukan dengan mengalikan nilai eigenvector alternatif dengan nilai eigenvector kriteria. Langkah selanjutnya melakukan pengecekan konsistensi logis untuk semua elemen dikelompokkan secara logis dan diperingatkan secara konsisten sesuai dengan suatu kriteria yang logis.

Matriks bobot yang diperoleh dari hasil perbandingan secara berpasangan tersebut harus mempunyai hubungan kardinal dan ordinal. Perhitungan Rasio Konsistensi dilakukan ini digunakan untuk memastikan bahwa rasio konsistensi $(\mathrm{CR}) \leq 0,1$. Jika nilai $\mathrm{CR}>0,1$ maka matriks perbandingan berpasangan harus dihitung ulang. Hasil perhitungan rasio konsistensi dapat dilihat pada Gambar 3 berikut.

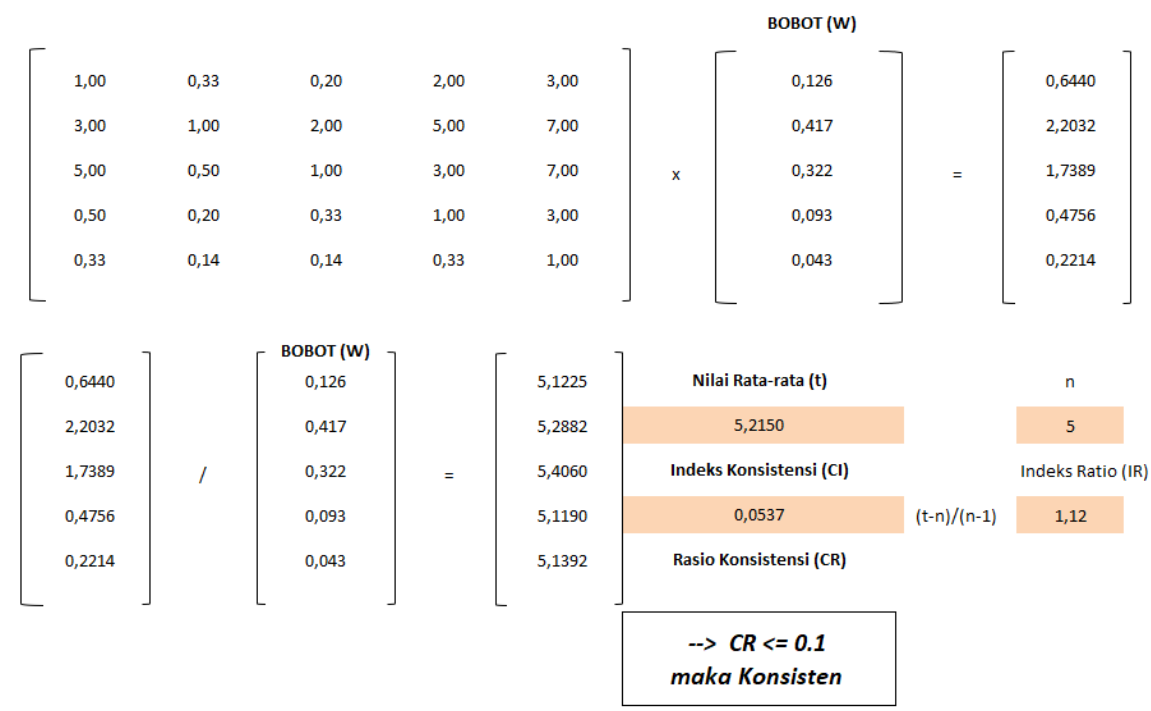

Gambar 3. Uji Konsistensi

Dari perhitungan di atas, nilai $\mathrm{CR}<0,1$ sehingga perhitungan rasio konsistensi dari perhitungan kriteria dapat diterima. Selanjutnya adalah menghitung nilai CR dari masih masing komponen servqual, Perhitungan dilakukan dengan cara yang sama dengan penghitungan kriteria yaitu 
menghitung perbandingan berpasangan, menghitung matriks nilai, menjumlahkan setiap baris, setelah itu dapat dihitung nilai rasio konsistensinya. Intensitas setiap kriteria memiliki nilai yang identik sehingga perhitungan intensitas hanya dilakukan satu kali. Dengan menggunakan rumus yang sama dengan perhitungan kriteria, diperoleh tabel-tabel perhitungan intensitas sebagaimana Tabel 10 berikut.

Tabel 10. Bobot Sub Kriteria Pada Variabel Dimensi Servqual

\begin{tabular}{|c|c|c|l|c|c|}
\hline No. & Variabel & Bobot & \multicolumn{1}{l|}{ No. } & Variabel & Bobot \\
\hline 1. & X1.1 & 0,44 & & X3.4 & 0,10 \\
\hline 2. & X1.2 & 0,17 & 17. & X3.5 & 0,16 \\
\hline 3. & X1.3 & 0,18 & 18. & X3.6 & 0,04 \\
\hline 4. & X1.4 & 0,05 & 19. & X4.1 & 0,14 \\
\hline 5. & X1.5 & 0,09 & 20. & X4.2 & 0,35 \\
\hline 6. & X1.6 & 0,08 & 21. & X4.3 & 0,23 \\
\hline 7. & X2.1 & 0,38 & 22. & X4.4 & 0,06 \\
\hline 8. & X2.2 & 0,11 & 23. & X4.5 & 0,13 \\
\hline 9. & X2.3 & 0,09 & 24. & X4.6 & 0,10 \\
\hline 10. & X2.4 & 0,05 & 25. & X5.1 & 0,31 \\
\hline 11. & X2.5 & 0,13 & 26. & X5.2 & 0,13 \\
\hline 12. & X2.6 & 0,24 & 27. & X5.3 & 0,08 \\
\hline 13. & X3.1 & 0,09 & 28. & X5.4 & 0,10 \\
\hline 14. & X3.2 & 0,42 & 29. & X5.5 & 0,16 \\
\hline 15. & X3.3 & 0,19 & 30. & X5.6 & 0,21 \\
\hline
\end{tabular}

\section{Nilai Servqual Terbobot}

Pada tahap ini akan dilakukan perhitungan nilai servqual terbobot, dimana nilai Service Quality adalah nilai yang diperoleh dari selisih persepsi responden terhadap kualitas layanan yang diterima dengan harapan responden terhadap kualitas layanan yang diberikan oleh Dekranasda Kabuapten Rembang. Jika suatu kriteria memiliki selisih positif, hal ini menunjukkan bahwa pihak penyedia jasa telah mampu memberikan jasa sesuai dengan yang diharapkan pelanggan. Sedangkan apabila suatu kriteria memiliki selisih negatif berarti bahwa pihak penyedia jasa belum mampu memenuhi harapan pelanggan terhadap kriteria kualitas layanan tersebut. Selanjutnya nilai servqual terbobot dapat diperoleh dengan mengalikan nilai Servqual tanpa bobot terhadap bobot kriteria. Pada Tabel 11 ditampilkan hasil nilai servqual terbobot yang diperoleh.

Tabel 11. Nilai Servqual Terbobot

\begin{tabular}{|c|c|c|c|c|c|}
\hline No. & Variabel & $\begin{array}{c}\text { Bobot } \\
\text { Dimensi }\end{array}$ & $\begin{array}{c}\text { Bobot Sub } \\
\text { Kriteria }\end{array}$ & Servqual & $\begin{array}{l}\text { Servqual } \\
\text { Terbobot }\end{array}$ \\
\hline 1 & $\mathrm{X} 1.1$ & \multirow{6}{*}{0,13} & 0,44 & $-0,744$ & $-0,327$ \\
\hline 2 & $\mathrm{X} 1.2$ & & 0,17 & $-0,324$ & $-0,055$ \\
\hline 3 & $\mathrm{X} 1.3$ & & 0,18 & $-0,002$ & 0,000 \\
\hline 4 & $\mathrm{X} 1.4$ & & 0,05 & $-0,313$ & $-0,016$ \\
\hline 5 & $\mathrm{X} 1.5$ & & 0,09 & 0,127 & 0,011 \\
\hline 6 & X1.6 & & 0,08 & $-0,302$ & $-0,024$ \\
\hline 7 & $\mathrm{X} 2.1$ & \multirow{6}{*}{0,42} & 0,38 & $-0,284$ & $-0,108$ \\
\hline 8 & $\mathrm{X} 2.2$ & & 0,11 & $-0,465$ & $-0,051$ \\
\hline 9 & $\mathrm{X} 2.3$ & & 0,09 & 0,189 & 0,017 \\
\hline 10 & $\mathrm{X} 2.4$ & & 0,05 & 0,005 & 0,000 \\
\hline 11 & $\mathrm{X} 2.5$ & & 0,13 & $-0,373$ & $-0,048$ \\
\hline 12 & $\mathrm{X} 2.6$ & & 0,24 & $-0,335$ & $-0,080$ \\
\hline 13 & X3.1 & \multirow{6}{*}{0,32} & 0,09 & 0,016 & 0,001 \\
\hline 14 & X3.2 & & 0,42 & 0,047 & 0,020 \\
\hline 15 & $\mathrm{X} 3.3$ & & 0,19 & $-0,031$ & $-0,006$ \\
\hline 16 & X3.4 & & 0,1 & 0,218 & 0,022 \\
\hline 17 & X3.5 & & 0,16 & 0,089 & 0,014 \\
\hline 18 & X3.6 & & 0,04 & 0,293 & 0,012 \\
\hline 19 & $\mathrm{X} 4.1$ & \multirow{2}{*}{0,09} & 0,14 & $-0,155$ & $-0,022$ \\
\hline 20 & $\mathrm{X} 4.2$ & & 0,35 & $-0,205$ & $-0,072$ \\
\hline
\end{tabular}




\begin{tabular}{|c|c|c|c|c|c|}
\hline 21 & $\mathrm{X} 4.3$ & & 0,23 & $-0,115$ & $-0,026$ \\
\hline 22 & $\mathrm{X} 4.4$ & & 0,06 & $-0,184$ & $-0,011$ \\
\hline 23 & $\mathrm{X} 4.5$ & & 0,13 & 0,249 & 0,032 \\
\hline 24 & $\mathrm{X} 4.6$ & & 0,1 & $-0,253$ & $-0,025$ \\
\hline 25 & X5.1 & \multirow{6}{*}{0,04} & 0,31 & $-0,033$ & $-0,010$ \\
\hline 26 & X5.2 & & 0,13 & $-0,371$ & $-0,048$ \\
\hline 27 & X5.3 & & 0,08 & $-0,184$ & $-0,015$ \\
\hline 28 & X5.4 & & 0,1 & 0,107 & 0,011 \\
\hline 29 & X5.5 & & 0,16 & $-0,011$ & $-0,002$ \\
\hline 30 & X5.6 & & 0,21 & 0,176 & 0,037 \\
\hline
\end{tabular}

\section{Analisis Service Quality Terbobot}

Servqual Terbobot Kriteria-kriteria kualitas layanan yang segera harus diperbaiki adalah kriteria yang mempunyai gap terbobot lebih besar dari nilai gap rata-rata, seperti terlihat pada Tabel 12 . Pada Tabel 12 terlihat bahwa terdapat 10 (sepuluh) variabel penilaian yang memiliki nilai servqual terbobot lebih tinggi dibandingkan dengan nilai rata-ratanya. Oleh karena itu, ke sepuluh kriteria tersebut harus segera mendapatkan perhatian dan solusi yang tepat untuk meningkatkan kualitas pelayanan Dekranasda Kabupaten Rembang.

Tabel 11. Nilai Servqual Terbobot

\begin{tabular}{|c|c|c|c|c|}
\hline No. & Variabel & $\begin{array}{c}\text { Bobot Sub } \\
\text { Kriteria }\end{array}$ & Servqual & $\begin{array}{c}\text { Servqual } \\
\text { Terbobot }\end{array}$ \\
\hline 1 & $\mathrm{X} 2.6$ & 0,24 & $-0,744$ & $-0,178$ \\
\hline 2 & $\mathrm{X} 2.1$ & 0,38 & $-0,324$ & $-0,123$ \\
\hline 3 & $\mathrm{X} 3.5$ & 0,16 & $-0,313$ & $-0,050$ \\
\hline 4 & $\mathrm{X} 3.1$ & 0,09 & $-0,302$ & $-0,027$ \\
\hline 5 & $\mathrm{X} 2.4$ & 0,05 & $-0,284$ & $-0,014$ \\
\hline 6 & $\mathrm{X} 1.4$ & 0,05 & $-0,465$ & $-0,023$ \\
\hline 7 & $\mathrm{X} 4.3$ & 0,23 & $-0,373$ & $-0,086$ \\
\hline 8 & $\mathrm{X} 3.2$ & 0,42 & $-0,335$ & $-0,141$ \\
\hline 9 & $\mathrm{X} 5.5$ & 0,16 & $-0,031$ & $-0,005$ \\
\hline 10 & $\mathrm{X} 1.5$ & 0,09 & $-0,155$ & $-0,014$ \\
\hline
\end{tabular}

\section{Rekomendasi Perbaikan}

Rekomendasi perbaikan yang harus segera dilakukan oleh pihak Dekranasda Kabupaten Rembang sebagaimana analisis servqual terbobot diantaranya karyawan dapat diandalkan dalam menangani masalah jasa pelanggan, meningkatkan komunikasi serta memberikan informasi semua produk yang dijual dengan baik sehinggan pelanggan terpacu untuk memberi produk pada Dekranasda Kabupaten Rembang. Dekranasda diharapakan meningkatkan kemamuan karyawan dengan mengikuti pelatihan-pelatihan. Pelayanan sesuai dengan janji yang diberikan, saat ini pengunjung dan pelanggan Dekranasda masih kurang puas dengan adanya produk yang ditawarkan, sehinggan kurang menarik untuk dikunjungi ulang, Dekrnasda harus memberikan layanan lebih baik dan meningkat.

Rekomendasi berikutnya adalah karyawan harus merespon permintaan pelanggan dengan cepat, tepat dan efisien, diantaranya dengan pemberian informasi harga, jenis produk yang dijual, spesifikasi produk, terutama produk batik. Karyawan diharapkan mampu memberikan jenis motifmotif batik dan makna dari motif tersebut. Peningkatan kesabaran dan perhatian pelayanan terhadap pelanggan juga perlu ditingkatkan melalui upaya untuk mengawal setiap pelanggan dalam melakukan transaksi produk. Dekranasda diharapkan menggunakan media teknologi informasi untuk peningkatan pemasaran dan informasi produk sehinggan pelanggan dapat mengakses produkproduk dengan baik. Sarana dan prasaran juga harus ditingkatkan diantaranya ruang tunggu yang nyaman, penataan produk yang lebih variatif dan menarik.

\section{KESIMPULAN}

Kriteria-krireria pelayanan dalam dimensi servqual memiliki 10 gap tertinggi untuk segera diperbaiki, semua gap memiliki nilai negati yang berarti tingkat harapan pelayanan terhadap pelanggan lebih tinggi terhadap persepsi yang diterimanya. Hal ini mendesak untuk dilakukan 
upaya-upaya perbaikan layan pada 10 (sepuluh) kriteria tersebut, dengan tidak mengesampingkan peningkatan pelayanan pada kriteria-krieria yang lainnya.

Kualitas layanan yang paling tinggi dan mendesak diperbaiki adalah karyawan dapat diandalkan dalam menangani masalah jasa pelanggan, Peningkatan informasi produk pada pelanggan, serta peningkatan sarana dan prasarana pada Dekranasda Kabupaten Rembang.

\section{DAFTAR PUSTAKA}

Awasthi A, Sayyadi R, Khabbazian A, 2018, A combined approach integrating gap analysis, QFD and AHP for improving logistics service quality, Int. J. Logistics Systems and Management, Vol. 29, No. 2.

Behdioglu B, Acar E and Burhan HA., 2017, Evaluating service quality by fuzzy SERVQUAL: a case study in a physiotherapy and rehabilitation hospital, Total Quality Management \& Business Excellence, ISSN: 1478-3363 (Print) 1478-3371 (Online)

Darmanto E, 2014, Penerapan Metode Ahp(Analythic Hierarchy Process)Untukmenentukan Kualitas Gula Tumbu, Jurnal SIMETRIS, Vol. 5, No. 1, ISSN:2252-4983

Gao C and Zhou Y, 2018, Research on quality of banking services based on QFD and SERVQUAL model, Int. J. Services Operations and Informatics, Vol. 9, No. 4, 20

Shirouyehzad H, Hosseinzadeh Lotfi, F.H, Arabzad M, Dabestani R, 2013, An AHP/DEA ranking method based on service quality approach: a case study in hotel industry, Int. J. Productivity and Quality Management, Vol. 11, No. 4.

Hosseini MH., Keshavarz E, 2017, Using fuzzy AHP and fuzzy TOPSIS for strategic analysis measurement of service quality in banking industry, Int. J. Applied Management Science, Vol. 9, No. 1, 2017

Juanzon JBP, 2019, Expectations and Perceptions in Engineering Consulting Project Management Quality Services: A Gap Analysis Using AHP Method and SERVQUAL Model, International Journal of Innovation, Management and Technology, Vol. 10, No. 1.

Kumar, S., Strandlund, E., dan Thomas, D. (2008). Improved service system design using Six Sigma DMAIC for major US consumer electronics and appliance retailer. International Journal of Retail \& Distribution Management, 36(12), 970994Shirouyehzad H, Farhad

Lupo T, 2013, Strategic Analysis of Transit Service Quality Using Fuzzy AHP Methodology, European Transport $\backslash$ Trasporti Europei, Issue 53, Paper n ${ }^{\circ}$ 5, ISSN 1825-3997

Parasuraman, A., V. A. Zeithaml, dan Berry, L. L,. (1985). A Conceptual Model of Service Quality and Its Implications for Future Research. Journal of Marketing, 49, 41-50

Pekkaya M, Imamoglu OP., dan Koca H, 2017, Evaluation of healthcare service quality via Servqual scale: An application on a hospital, International Journal Of Healthcare Management, ISSN: $2047-9700$ (Print) 2047-9719 (Online),

Rahman R, 2019, Penerapan Metode AHP Untuk Menentukan Kualitas Pakaian Jadi di Industri Garment, Jurnal Informatika, Vol.6 No.1 April 2019, pp. 1-8, ISSN: 2355-6579, E-ISSN: 2528-2247.

Singh A.K, 2016, Competitive service quality benchmarking in airline industry using AHP", Benchmarking: An International Journal (Emerald), Vol. 23

Syafitri LS, Herlawati, 2016, Penilaian Kualitas Pelayanan Digital LoungeMenggunakan Metode Servqual dan Analitycal Hierarchy Process, Bina Insani Ict Journal, Vol.3, No.1, Juni 2016, 73-84, ISSN:2355-3421 (Print) ISSN:2527-9777 (Online).

Udo, G. J. (2011). Using SERVQUAL to assess the quality of e-learning experience. Computers in Human Behavior.

Yazdi A.K, 2015, Designing a mathematical model for indicators of service quality in the tourism industry based on SERVQUAL and Rembrandt methods, Int. J. Productivity and Quality Management, Vol. 15, No. 4, 2015

Zhu JC, Ramanathan R., and Ramanathan U., 2011, Measuring Service Quality using SERVQUAL and AHP: an application to a Chinese IT company and comparison, Int. J. Services and Operations Management, Vol. 8, No. 4. 